\title{
Research on the Current Condition of College Tourism Personnel Training Mode and Vocational Education Reforms
}

\author{
Benqian Zhao ${ }^{1}$ \\ 1 qinhuangdao Institute of Technology, \\ Qinhuangdao,Hebei,066100 China
}

\begin{abstract}
In this paper, we conduct research on the current condition of college tourism personnel training mode and vocational education reforms. Paying attention to the current social development innovation spirit, how to make students possess the necessary ability to innovate, is this the prime problem of the education. A lot of highly educated personnel in order to better adapt to social development and changes, constantly to learn knowledge, also has the characteristics of vocational college students. Our research combines the characteristics of the college tourism personnel training mode with the education reform which will enhance the performance of the teaching process.
\end{abstract}

Keywords: Training Mode; Tourism Personnel; Education Reforms; Literature Review.

\section{Introduction}

With the establishment of the market economic system, scientific and technological progress and industrial structure adjustment and has changes in the labor market. The present situation of higher vocational education has more and more don't meet the need of cultivating high-quality workers and senior talents, can satisfy the people's growing diversification vocational education needs. I mouth mechanism of education, curriculum pattern, the management system has been lagging behind the pace of the modern economic development, seriously restricted the healthy development of vocational education in our country. In reality, China's vocational education teaching quality evaluation system is still very much in the lineage of subject education teaching quality evaluation system. Give priority to in order to return to teaching, most of the vocational education curriculum evaluation system or around the subject of classroom teaching, rarely on practice, aiming at ability training for vocational education teaching quality can, evaluation, based on the discipline education teaching quality evaluation system doesn't reflect professional characteristics and the practical feature of vocational education [1]. The formation of this situation, on the one hand, is also in constant development of vocational education reform, the teaching mode is not mature, on the other hand is to adapt to the reform of vocational education teaching quality evaluation system to build the relative lag and the development of vocational education. Discipline education class teaching quality evaluation system and vocational education and practical features of the growing contradiction of professional characteristics, in order to improve vocational education teaching quantity. It is imperative to reform vocational education teaching quality evaluation system.

The current condition and challenges of the vocational education could be summarized as follows. (1) Due to some social injustices, some shortcomings of school management system, and some parents bad precept. Cause the students to understand the deviation. (2) Long-term caused by "traditional knowledge imparting type education" thinking occlusion and the rigidity of thinking, lack of associative thinking and divergent thinking ability. (3) Student to teacher's criticism education ignored, often teach not to 
change which can only make political thought work, make criticism education, but often ineffective. (4) The activities of people which are generally caused by certain motive. Students to study are always dominated for certain learning motivation. Learning motivation is directly promote students to study a kind of internal motivation.

The existing tourism talents in China, at the hotel, travel agency, or other personnel with a travel companies have a wealth of practical experience, but in comparison, the theoretical knowledge is imperfect. Poor management level and development potential, and colleges and universities graduates which will accepted the education system of theory, master the cutting-edge information, but practical experience was particularly scarce, it is difficult to immediately or soon after graduation equal to the upper management of tourism. In addition, to cultivate comprehensive tourism talents in our country have not form a system of training institutions and perfect training channels. The overall quality of vocational education of talent training should have certain professional pertinence, this is the mission of social development put forward to talents training in higher vocational colleges and the different professional category should reflect different requirements and focus. Tourist class to the cultivation of students' comprehensive quality in higher vocational colleges, in the unity of universal demand at the same time, also should reflect the tourism industry. At present, the academia for innovative talents is mainly from aspects such as innovation consciousness, innovation spirit and innovation ability of interpretation. However, innovation is not only the embodiment of the innovative quality, should also highlight the action characteristics of innovative talents. At the same time, innovation is not changed, the grandstanding, but on the basis of the coordinated development of their comprehensive quality sublimation of a new creation consciousness and creation ability, has the basic intrinsic quality and industry standards, after a long hard work, repeated exploration is needed to achieve a kind of state. In the following figure one, we demonstrate the structure and organization of the Chinese education.

\begin{tabular}{|c|c|c|}
\hline Levels of Education & General Education & $\begin{array}{c}\text { Vocational Education and } \\
\text { Training } \\
\end{array}$ \\
\hline Tertiary Education & $\begin{array}{c}\text { Universities } \\
\text { - Undergraduate studies } \\
\text { - Graduate studies } \\
\text { - Post-doctoral studies }\end{array}$ & $\begin{array}{l}\text { - Polytechnic colleges } \\
\text { - Specialized junior colleges } \\
\text { - Technician colleges }\end{array}$ \\
\hline Higher Secondary Education & - General senior high schools & $\begin{array}{l}\text { - Specialized high schools } \\
\text { - Vocational high schools } \\
\text { - Skilled worker schools } \\
\text { - Adult specialized high schools } \\
\text { - Short-term courses of various } \\
\text { types }\end{array}$ \\
\hline Lower Secondary Education & - General junior high schools & $\begin{array}{c}\text { - Vocational junior high schools } \\
\text { - Short-term courses of various } \\
\text { types }\end{array}$ \\
\hline $\begin{array}{l}\text { Primary Education } \\
\text { Pre-school Education }\end{array}$ & $\begin{array}{l}\text { - Primary schools } \\
\text { - Pre-schools }\end{array}$ & \\
\hline
\end{tabular}

Figure 1.The Structure and Organization of the Chinese Education

In this paper, we conduct research on the current condition of college tourism personnel training mode and vocational education reforms. China's higher education from the elite stage into the popularization stage and the coming of the era of mass education means the general industrialization and marketization of higher education. Analysis of the structure of the training is the target. We can see that the cultivation of tourism talents in our country [2]. China has already formed the three tourism talents training school, undergraduate and graduate levels. Graduation number of tens of thousands of people each year for the development of tourism in China provides a large 
number of talents. In the next sub-sections, we will discuss the issues in detail.

\section{The Proposed Methodology}

The Vocational Education Reforms. The professional quality of the vocational education through is nephew's practitioners which can affect a country's overall national quality and even the survival and development. In today's China, various aspects gradually with the international community, in education are also undergoing a profound change. The value of education is no longer just to foster a small number of "elite", for people of all different potential lies in whether to provide equal, to maximize the opportunity to develop their ability and way and lay the road to success under everyone's feet. Our era is the age of rapid development of science and technology with each passing day. Science and technology into productivity speed directly and lead to a career change speed than at any other time in history. High and new technology development and application of inevitably lead to social and economic change of worker quality requirements, necessary to serve the economic development and to cultivate applied talents of vocational education have a significant impact, inevitable requirement occupational education in such aspects as goal, content, means, make a major adjustment, must put forward new requirements for vocational education course. Therefore, vocational education must take the initiative to adapt to the requirements of the scientific and technological progress and economic development, through the curriculum reform, strengthen the cultivation of vocational school to the students' vocational ability, make the vocational school students, not only is the owner of knowledge, skills which should also become the transformation of knowledge, skills, be capable to adapt to changes in professional talents.

In the process of actual operation, vocational colleges should give full play to their initiative, adhere to the principle of openness, and on thought, for example, to set up a complete market research mechanism, often into the cooperation in the enterprise to understand market demand, to find the advantages and disadvantages in the process of vocational education, thus achieves real-time change according to the problem of vocational education development direction and goals. Vocational education should attach great importance to the students' vocational guidance, make its soluble people into school education idea, raises the student good psychological quality of employment. Some students lack of understanding, there are many problems in the employment awareness, some high expectations, dependence is strong some old ideas, heavier inferiority mentality, the phenomenon directly affect the smooth employment of the graduates. Therefore, to strengthen the guidance and can well adapt to society and the number of students in vocational schools, school education is an important task. Investigation without partnership enterprise the actual demand for talent, according to circumstances to adjust course education, knowledge structure and so on, causes the student to reach the standard of choose and employ persons of the enterprise which will be meaningful and helpful.

The College Tourism Personnel Training. The tourism industry and university cooperation, at present just stop at a low level of cooperation level, the lack of long-term, holds the system of cooperation. Students to the hotel, travel agencies and other tourism enterprises to practice is just do some simple repeated operation, tourism enterprises is not to let the students field operations. And foreign students internship is directional, such as students go to the hotel practice, must to the hotel each department intern, and not just do the waiter or the main dish, in this way, the student completes, the can overall operation of the hotel has a very deep of perceptual knowledge, and after graduation for hotel each department work competence. Practice such as practice teaching must be 
combined and tourism enterprises. Let students direct field operation, realize the alternately, with learning. As far as possible to participate in every link of the operation of the enterprise get the umbrella in the process of training, guarantee the quality of practice, and improve the effect of practice courses.

In the process of practice, hire experienced guide technicians and management personnel. This can arouse the students' enthusiasm and initiative practice on one hand, on the other hand can make the students familiar with the characteristics and rules of the operation of the enterprise culture and the ability to exercise students qualified for professional post, the integrated use of learned knowledge and skills to solve the food industry in the operation of the common and accidental problem, make the better combination of theory and practice foundation for direct mount guard work after graduation, to realize the seamless connection between graduation and employment. Practice outside the colleges and universities should pay attention to the students, training process supervision, evaluation. Schools should make special arrangements to guide teachers is responsible for organizing, coordinating student internship. Arrange appropriate post by the tourism enterprises and seasoned industry experts and business training, guidance to students. Students and teachers to make preparations for internship before which should understand the basic situation and practice the basic content internship units. Formulate corresponding internship program, completes the practice of psychological preparation.

The internship units to make short-term pre-service training for students. Teachers should communicate with students, more interactive, through on-the-spot guidance, Internet, telephone and other timely communication with students, guiding students to enhance the sense of responsibility, abide by the requirements internship units. Students are encouraged to frequently observed, brain thinking, encourage students calmly properly deal with all sorts of problems encountered in the practice process, actively involved in the practice activity, improve the practice ability, innovation consciousness, coordination and communication skills and team cooperation ability. Collect the student to the practice base evaluation opinions [3]. Higher vocational tourism management major should combine the actual conditions of tourism development to further deepen the reform.

The Suggestions and the Prospect. At present, many schools have their own strong professional, vocational colleges is not exceptional also, often school in developing their own traditional professional advantage, can according to their own economic strength, the teachers level and knowledge structure to formulate relevant professional development goals. But with the rapid development of society, the traditional advantage majors are also able to adapt to the development of the society change became an uncertain problem. Therefore, vocational schools should change the way of the development of the isolated, and starting from the real needs of society, to establish an open system of the vocational education aim. The suggestions for the development of the vocational education could be summarized as the follows. (1) Accurate positioning, adhere to the service society's educational philosophy. Research needs, understand requirements, to adapt to the demand, the demand for services, is the vitality of higher vocational education personnel training. Here of demand in both the number of personnel training, there is also a personnel training specification aspect. There are both teaching content, teaching methods. (2) As its important to practitioners, vocational college should establish "win-win" mode of production, inspire the enthusiasm of enterprises involved in co-operative, which should guarantee enterprise can benefit from it. Such as vocational and technical college can use all kinds of teaching resources for the enterprise on-the-job personnel 
training, on the cultivation of talents, the colleges should satisfy the requirement of the enterprise and hope, as far as possible the reference unit of choose and employ persons to cultivate college students revised teaching plan, adjust the course arrangement. (3) We will intensify reform of teaching links, the establishment of an open course system. To professional ability as the standard, is to build the employment guide the focus of vocational education development pattern. Emphasis on professional ability, professional practice ability, vocational college professional setting and the curriculum teaching should be based on the career in the post requirements to design, the curriculum must be from subject system to turn to professional guidance and work process oriented model.

\section{Conclusion}

In this paper, we conduct research on the current condition of college tourism personnel training mode and vocational education reforms. As a professional colleges and universities the first thing to do is starting from the actual needs of training objects, fundamentally solve training their purpose. In addition, the school also should change their old serving the social development goal, development towards the goal to provide a wide range of education and training services, the education scale, structure, quality, benefit, penetration into vocational education and training, fulfil for educate to provide more diversified and more facilitation services. The traditional vocational education to the student, the end of a single type of work is to train and develop education to strengthen the skills training for the single type of work, to adapt to the planned economic system and to meet the requirements of economic development is relatively slow. In conclusion, although the development of vocational education still faces many difficulties, but as long as we work together to make the government, enterprises, schools, and individual's enthusiasm for common development and the further modification, vocational education will have a bright future.

\section{References}

[1] Li Q L, Ren J, University Y N. College Tourism Professional Personnel Training Mode of "Three Hit" Concept[J]. Education \& Teaching Research, 2014.

[2] Wang J, Gai Y, Wang L. The Exploration and Practice of Personnel Training Mode of Triple Win of College,Enterprise and Student-A Case Study of Hotel Management Specialty[J]..

[3] Xiang Y, Zhang H, Tourism C O, et al. The New Second Classroom in the Era of the Internet And Personnel Cultivation[J]. Meitan Higher Education, 2014. 